\title{
STUDI LITERATUR TAHAPAN PROSES BERPIKIR KREATIF SISWA MELALUI REALISTIC MATHEMATICS EDUCATION
}

\author{
Vivi Novitasari \\ Program Studi Pendidikan Guru Sekolah Dasar, Fakultas Psikologi dan Ilmu \\ Pendidikan, Universitas Muhammadiyah Sidoarjo \\ vivinovita009@gmail.com \\ Mohammad Faizal Amir \\ Program Studi Pendidikan Guru Sekolah Dasar, Fakultas Psikologi dan Ilmu \\ Pendidikan, Universitas Muhammadiyah Sidoarjo \\ faizal.amir@umsida.ac.id
}

\begin{abstract}
Abstrak
Salah satu pendekatan pembelajaran berbasis masalah-masalah kontekstual, yaitu Realistic Mathematics Education (RME) telah terbukti dapat mengeksplorasi dan meningkatkan berpikir kreatif siswa. Penelitian ini bertujuan untuk mengidentifikasi langkah-langkah RME untuk meningkatkan berpikir kreatif siswa yang mengacu pada prinsip dan karakteristik RME. Penelitian ini menggunakan study literature. Terdapat lima tahapan proses berfikir kreatif siswa melalui RME, yakni tahap orientasi siswa membaca dan memahami masalah. Tahap persiapan siswa membaca ulang masalah, mencari informasi dari buku dan bertanya kepada guru. Tahap inkubasi siswa membaca ulang informasi yang didapat dari tahap persiapan, dan merumuskan strategi. Tahap iluminasi siswa memikirkan ide, menganalisis ide, menghubungkan dan mengaitkan ide kedalam solusi dan menyelesaikan masalah. Tahap verifikasi siswa memeriksa ide atau jawaban.
\end{abstract}

Kata Kunci: Matematika Realistik, Kontekstual, Berpikir Kreatif

\begin{abstract}
One approach to learning based on contextual problems, namely Realistic Mathematics Education (RME), has been proven to explore and improve students' creative thinking. This study aims to identify RME steps to improve students' creative thinking that refers to the principles and characteristics of RME. This research uses a literature study. There are five stages of students' creative thinking process through RME: the orientation stage of students reading and understanding problems. Students reread the problem, look for information from books, and ask the teacher in the preparation stage. In the incubation stage, students reread the information obtained from the preparation stage and formulate strategies. Students think about ideas, analyze ideas, connect and link ideas into solutions, and solve problems in the illumination stage. Verification stage, students check ideas or answers.
\end{abstract}

Keywords: Realistic Mathematics, Contextual, Creative Thinking 


\section{PENDAHULUAN}

Proses pembelajaran yang dilakukan dengan cara yang tepat dan sesuai akan memberikan dampak baik kepada siswa. Proses pembelajaran juga akan membantu siswa dalam proses penyelesaian masalah yang mereka hadapi. Cara yang dilakukan siswa dalam proses memecahkan suatu masalah dilakukan dengan strategi yang berbeda-beda. Tidak semua siswa memiliki cara yang sama dan waktu yang sama untuk menemukan suatu hal sebagai pemecah masalah yang ada. Seperti halnya dalam menyelesaian masalah dari materi pecahan. Dalam memecahkan atau menyelesaikan masalah, mereka pasti memiliki cara, strategi, dan pemikiran yang berbeda.

Materi pecahan dengan angka yang jarang diketahui pada siswa sekolah dasar akan menimbulkan kesulitan dalam memahami dan memecahkan masalah pecahan (Saleh et al., 2018). Banyak siswa yang tidak mampu memahami konsep pecahan dalam waktu yang cepat, hal ini karena konsep pecahan dengan 2 angka berbeda dalam satu bilangan pecahan tetapi melambangkan bagian dari suatu yang utuh (Heruman, 2007).
Setiap siswa memerlukan waktu yang berbeda-beda dalam memahami suatu materi. Oleh karena itu, menyelesaikan sebuah masalah matematika perlu adanya pemahaman konsep pada diri siswa mengenai materi yang ada. Hal ini disebabkan karena belum memahami konsep dari materi yang disampaikan.

Pemberian materi oleh guru kepada siswa dengan pemahaman konseptual bukan lagi dengan metode prosedural dalam memecahkan masalah memberikan dampak baik pada perkembangan pengetahuan siswa. Perkembangan pengetahuan siswa berkembang sesuai dengan apa yang mereka terima. Semakin banyak apa yang mereka terima dan pelajari maka perkembangan pengetahuan akan berkembang. Perkembangan pengetahuan tersebut dapat dilakukan dengan mengetahui dari proses berpikir kreatif siswa.

Proses berpikir kreatif siswa merupakan sebuah perkembangan yang mengarahkan siswa dengan mememukan ide-ide baru. Pengembangan proses berpikir kreatif diantaranya dengan sebuah media kongkrit atau alat peraga. Media kongkrit merupakan suatu media nyata yang digunakan dalam penyampaian pesan kepada siswa. Media 
yang digunakan diarahkan menuju pemikiran siswa sehingga kemampuan berpikir kreatif mereka akan berkembang dan muncul. Kemampuan berpikir kreatif merupakan salah satu kemampuan yang harus dimiliki dan dikembangkan pada siswa dalam pembelajaran matematika (Purwaningrum, 2016). Upaya peningkatan proses pembelajaran matematika untuk mengembanagkan proses berpikir kreatif siswa harus dilakukan mulai sejak dini (Ichwatun, 2015). Melalui peningkatan ini siswa diharapkan mampu berpikir lebih luas dan dapat menentukan ide-ide baru melalui proses yang nyata dalam menyelesaikan masalah dalam hal pecahan.

RME merupakan suatu kerangka instruksional yang berdasarkan teori pedagogis dan kurikulum yang dikembangkan oleh Freudenthal Institute di Belanda (Hadi, 2018). Pembelajaran menggunakan RME diberikan suatu masalah konstektual yang sesuai dengan materi. Masalah konstektual merupakan masalah yang berkaitan dengan hal yang nyata yang ada di sekitar (Anggo, 2011). Masalah konstektual disajikan berupa masalah atau soal dengan konteks atau situasi yang terjadi dalam kehidupan sehari-hari siswa sebagai pemecah masalah.

Tahapan berpikir kreatif dalam proses pemecahan masalah dapat dilakukan dengan pengimplementasian pendekatan Realistic Mathematic Education (RME). Sehingga akan diketahui tahapan dan aspek proses berfikir kreatif. Tahapan berpikir kreatif siswa dengan menerapkan RME akan diiringi dengan proses berpikir kreatif siswa sesuai dengan 4 aspek yakni fluensy, flexibility, originality, dan elaborative. Sehingga dapat ditentukan kategori berpikir kreatif siswa mulai dari sangat tinggi, tinggi, sedang, lemah, dan sangat lemah (Sitorus \& Masrayati, 2016).

Kategori atau tingkatan berpikir kreatif akan menunjukkan hasil dari kemampuan siswa. Sejauh mana tingkatan dari berpikir kreatif siswa. Sehingga, penerapan RME dalam proses pembelejaran matematika akan memberikan dampak positif terhadap pengetahuan kognitif dan meningkatkan berpikir kreatif siswa.

Oleh karena itu, fokus artikel ini adalah mendeskripsikan tahapan proses berpikir kreatis siswa melalui RME pada materi pecahan dan langkah-langkah pembelajaran RME untuk meningkatkan berpikir kreatif siswa. 


\section{METODE}

Dalam penelitian ini menggunakan metode pendekatan studi literatur. Studi literatur dikenal sebagai studi pustaka, dengan batasan pada kegiatan ini hanya mengarah pada artikel, jurnal, serta koleksi dari perpustakaan saja tanpa memerlukan riset di lapangan. Penelitian ini dilakukan dengan cara mengumpulkan data dari literatur yang berasal dari jurnal atau artikel-artikel yang terkait dengan tahapan proses berpikir kreatif melalui RME.

Dalam Penelitian ini, Peneliti mengkaji serta menganalisis berbagai literatur yang telah dibaca dan dicatat untuk memperoleh hipotesis serta hasil penelitian dari studi literatur yang telah dilakukan oleh peneliti.

Teknik pengumpulan data pada penelitian ini dilakukan dengan cara mempelajari, mengkaji dan menghubungkan artikel-artikel atau jurnal yang terkait dengan penelitian ini. Pada penelitian ini data yang digunakan adalah data sekunder yang didapat dari penelitian orang lain yang tertulis dalam bentuk jurnal atau artikel yang terkait dengan penelitian sehingga mendapatkan informasi, data dan dasar teori untuk menganalisis dan pembahasan.

Sumber data yang dijadikan rujukan utama dalam penelitian ini adalah penelitian yang dilakukan oleh Jonni Sitorus \& Masrayati: 2016 dengan judul "Student's Creative Thinking Process Stages: Implementation of Realistic Mathematics Education"

Subjek dalam penelitian ini sesuai dengan literatur yang terkait pada fokus penelitian yang dilakukan oleh peneliti. Maka subjek dalam penelitian ini merupakan siswa Sekolah Dasar yang sudah diamati oleh peneliti-peneliti terdahulu yang sesuai dengan fokus penelitian ini.

Teknik analisis data dalam penelitian ini menggunakan analisis deskriptif dan analisis isi. Analisis data dalam penelitian ini dilakukan dengan melalalui 3 tahapan, yakni Reduksi data, penyajiam data, dan penarikan kesimpulan.

\section{HASIL DAN PEMBAHASAN}

Tahapan Pembelajaran RME Untuk Meningkatkan Berpikir Kreatif Siswa

Pada pembelajaran di kelas dengan menerapkan pendekatan Realistic Mathematic Education dalam penyampaian materi, siswa untuk menemukan konsep materi yang diajarkan secara mandiri dengan pemberian masalah yang bersifat konstektual. Proses pembelajaran dengan langkah-langkah pendekatan RME 
disusun dan dilakukan berdasarkan Gambar 1). prinsip dan karakteristik RME (Lihat

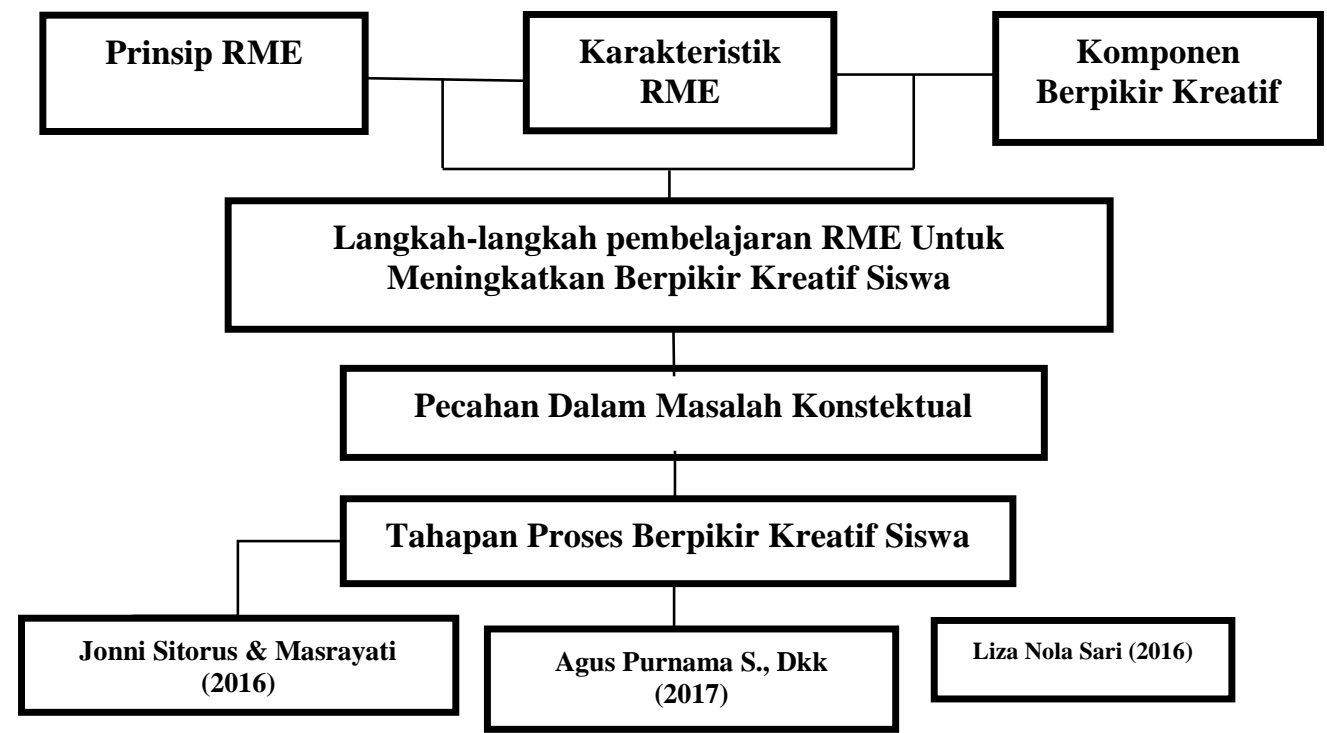

Gambar 1. Skema pembahasan

Langkah pertama: memahami pecahan berupa kejadian ulang tahun masalah konstektual. Pembelajaran awal siswa, kemudian dijelaskan dalam RME dimulai dengan pemberian menggunakan benda kongkrit berupa masalah konstektual untuk mengajak kapur tulis yang dibagi menjadi beberapa siswa mulai berpikir. Maka dengan hal ini ditekankan pada karakteristik RME Phenomological exploration or the use of contexts (menggunakan masalah kontekstual). Misalkan, guru membawa sebuah roti, dan guru berkata bahwa roti akan diberikan kepada 3 siswa yang aktif di kelas, kemudian guru bertanya berapa bagian yang diterima oleh masingmasing anak kepada siswa.

Sulistiyowati (2014) memberikan contoh berupa guru menyajikan masalah konstektual yang berkaitan dengan bagian. Hal ini mendapatkan respons baik, yang ditunjukkan saat guru mengajukan pertanyan siswa mampu menjawab dengan benar dan cepat.

Melalui permasalahan tersebut siswa akan mulai berpikir beberapa kemungkinan ide atau jawaban dari masalah. Siswa mulai mengungkapkan gagasan mereka dengan banyak kemungkinan jawaban yang berbedabeda. Maka pada hal ini aspek berfikir kreatif Fluency dimunculkan. Pada penelitian Nalole (2008) 
mengungkapkan bahwa ketika siswa diberikan suatu masalah dan ditanya mengenai masalah siswa mengajukan beberapa jawaban benar secara lancar dan spontanitas.

Langkah kedua: menyelesaikan masalah konstektual. Setelah disajikan masalah siswa diminta untuk menyelesaikan masalah yang diberikan secara berkelompok. Siswa diarahkan untuk berpikir menemukan suatu konsep dari masalah dengan menggunakan model matematisasi dan memberikan strategi-strategi baru yang dilakukan dengan media atau benda disekitarnya. Proses penyelesaian ditekankan pada prinsip RME yang pertama Guided Reinvention (Menemukan Kembali) dan karakteristik RME yang ke dua The Use Of Models Mathematics (Menggunakan Model matematika).

Siswa diarahkan untuk berpikir cara penyelesaianya konsep matemtaika menggunakan model matematiasasi (Dhoruri, 2010; Hasyim, 2017; Jupri, 2019; Manurung et al., 2019; Warsito et al., 2019). Sehingga siswa dapat menemukan sebuah konsep pecahan yang digunakan dengan memberikan berbagai jawaban dan strategi berbeda dari yang lain. Sehingga aspek berfikir kreatif yang ditunjukkan atau dimunculkan oleh siswa yakni Flexibility dan originality.

Langkah ketiga: membandingkan dan mendiskusikan jawaban. Siswa membandingkan dan mendiskusikan jawaban atau hasil penyelesaian mereka bersama teman dan guru. Guru berperan sebagai fasilitator sedangkan siswa lain diarahkan untuk memberikan tanggapan atau pertanyaan berdasarkan jawaban dari siswa lain. Adanya presentasi dari siswa maka akan diketahui bagaimana cara siswa dalam menyelesaikan masalah, apakah secara rinci atau langsung pada hasil. Aspek yang akan ditunjukkan oleh siswa yakni Elaborative dan Flexibility.

Kegiatan ini diarahkan dan ditekankan pada prinsip RME Dedactical Phemology (Fenomena Dedataktik) dan karakteristik RME The Use Of Student Own Productions And Cinstruction Or Student Contributions (Menggunakan Konstribusi Siswa). Siswa diberikan kesempatan untuk berpikir, menganalisis, menyelesaikan masalah dan mengutarakan pendapatnya dalam presentasi untuk dijelaskan bagaimana cara penyelesaian masalah yang dilakukan. Hal ini didapatkan siswa mampu menggunakan berbagai cara yang beragam (Dhoruri, 2010; Haryanti, 2017; Prianto et al., 2016) 
Langkah keempat: interaksi antara guru dan siswa. Interaksi antara guru dan siswa mengenai penyelesaian masalah, serta interaksi antara siswa dan siswa saat berdiskusi (presentasi, tanya jawab, dan memberikan tanggapan).

Penyelesaian masalah dilakukan dengan cara siswa sendiri dengan media atau benda yang ada disekitar siswa. Langkah ini menerapkan prinsip RME SelfDeveloped Models (pengembangan model sendiri) dan karakteristik RME The Interactive Character of The Teaching Procces Or Interactivity (Interaktivitas atau Interaksi).

Pada penelitian (Hasyim, 2017) langkah keempat mengarah pada komunikasi antara guru dan siswa mengenai masalah konstektual yang diberikan. Sedangkan (Dhoruri, 2010; Jupri, 2019) dilakukan dengan tanya jawab antar siswa bersama guru. Guru memberikan bimbingan siswa sampai diperoleh jawaban mereka sendiri.

Langkah kelima: menyimpulkan. Proses penyimpulan dilakukan oleh siswa kemudian diperjelas oleh guru yang dilakukan secara bersama-sama untuk mendapatkan jawaban dari pemecahan masalah mengenai materi yang dipelajari. Langkah terakhir ditenekankan pada karakteristik RME yang ke lima yakni The Interwining of
Various Larning Strands (keterkaitan dengan materi lain).

Siswa melakukan refleksi untuk memperoleh kesimpulan, kemudian guru memberikan penguatan materi dan menjelaskan bahwa materi yang dipelajari hari ini berhubungan dengan materi selanjutnya (Haryanti, 2017; Hasyim, 2017).

\section{Tahapan Proses Berpikir Kreatif Melalui RME Pada Materi Pecahan}

Terdapat perbedaan pendapat mengenai tahapan proses berpikir kreatif siswa melalui RME. Pada penelitian (Sitorus \& Masrayati, 2016) terdapat 5 tahapan proses berpikir kreatif siswa melalui RME yakni orientasi, persiapan, inkubasi, iluminasi dan verifikasi. Sedangkan penelitian (A. P. Sari et al., 2017; L. N. Sari, 2016) mengacu pada model Wallas dengan 4 tahapan proses berpikir kreatif yakni persiapan, inkubasi, iluminasi, dan verifikasi.

Tahapan proses berpikir kreatif dalam penelitian ini mengacu pada penelitian Sitorus \& Masrayati (2016) tahapan berpikir kreatif muncul ketika siswa menyelesaikan soal masalah konstektual (Lihat Tabel 2). 
Studi Literatur Tahapan Proses....

Tabel 1. Perbandingan Tahapan Proses Berpikir Kreatif

\begin{tabular}{cc}
\hline Sitorus \& Masrayati (2016) & $\begin{array}{c}\text { Sari, Ikhsan \& Saminan (2017), } \\
\text { Liza Nola Sari (2016) }\end{array}$ \\
\hline Orientasi & Persiapan \\
Persiapan & Inkubasi \\
Inkubasi & Iluminasi \\
Iluminasi & Verifikasi \\
Verifikasi & \\
\hline
\end{tabular}

Tabel 2. Tahapan proses berpikir kreatif (Jonni Sitorus \& Masrayati: 2016)

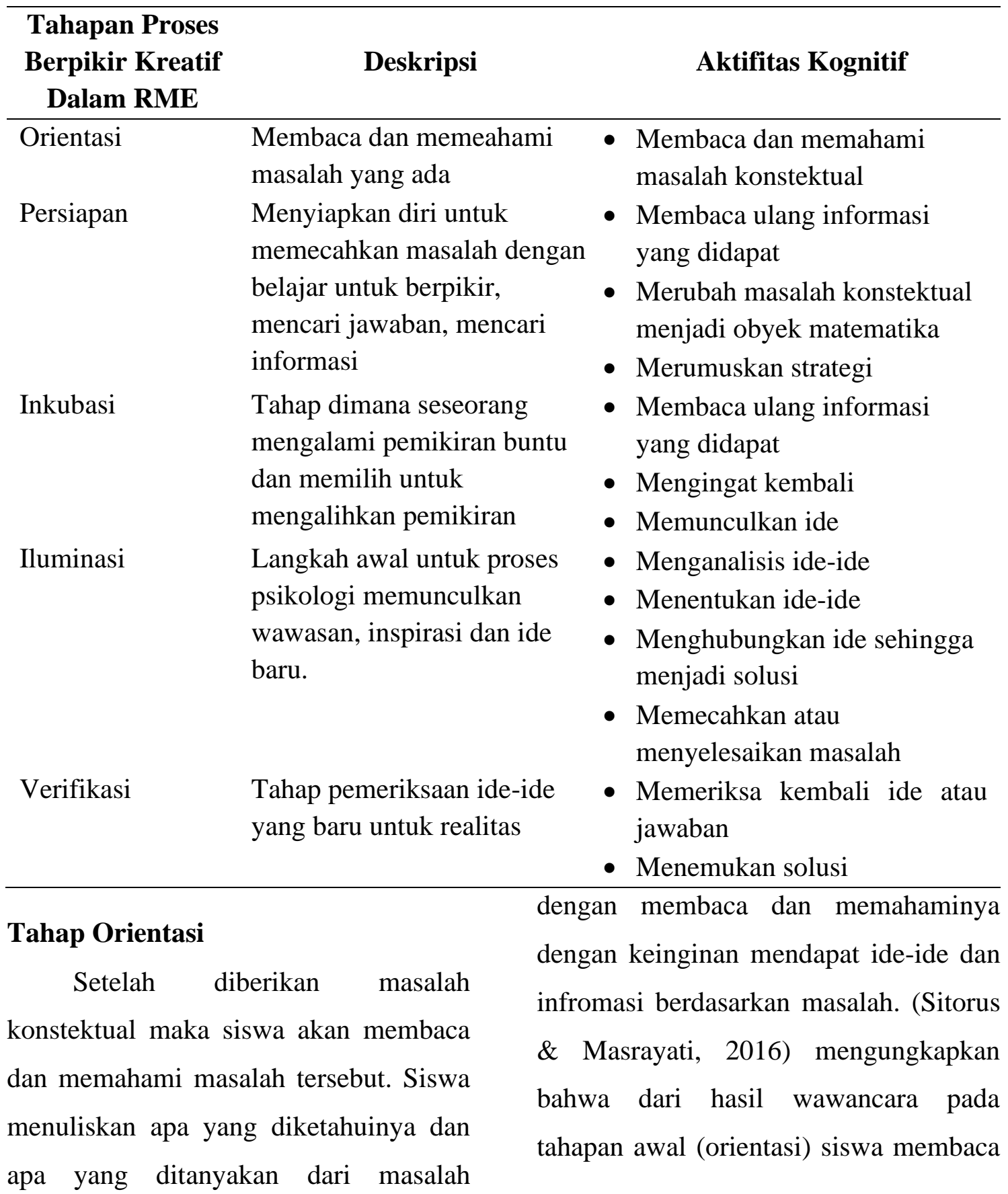


dan memahami semua masalah yang ada karena berkeinginan untuk mendapatkan ide-ide, mencari dan menemukan informasi dari masalah. Sedangkan dalam penelitian (A. P. Sari et al., 2017) mengungkapkan bahwa siswa memahami permasalahan dan informasi yang diberikan kemudian mencatat atau menuliskan informasi yang mereka dapatkan dengan bahasa mereka sendiri.

\section{Tahap persiapan}

Siswa membaca ulang informasi yang didapat dari masalah yang diberikan, kemudian siswa mencari informasi-informasi dari buku-buku yang terkait dengan materi pecahan dan menanyakan kepada guru mengenai apa yang tidak mereka pahami. Siswa mengubah masalah menjadi obyek matematika untuk merumuskan startegi selanjutnya dengan pegimplementasian sebuah benda atau media.

Siswa mengumpulkan informasi yang berhubungan dengan masalah konstektual dari buku-buku, siswa juga mengingat materi yang pernah didapatkan. Kemudian siswa mengidentifikasi bersama untuk menemukan alternatif jawaban sehingga siswa dapat merumuskan strategi pemecahan masalah (Putri et al., 2019; Sitorus \& Masrayati, 2016).
Sedangkan penelitian (Ardiansyah \& Sunaringtyas, 2016; A. P. Sari et al., 2017) siswa membaca beberapa kali untuk memecahkan permasalahan yang dihadapi dengan mencari pendekatan untuk menyelesaikannya. Penelitian lain yang sejalan yakni setelah membaca masalah siswa mengumpulkan informasi-informasi yang diperlukan dengan memilih informasi yang dibutuhkan dan informasi yang tidak dibutuhkan dalam penyelesaian masalah dengan tepat (Prianggono, 2010; L. N. Sari, 2016; Wulantina et al., 2015).

\section{Tahap Inkubasi}

Siswa hanya membaca ulang informasi yang didapat dari tahap sebelumnya dan mengingat kembali strategi yang telah dirumuskan. Pada tahap inkubasi siswa melakukan kegiatan lain seperti berbicara terhadap temannya, ataupun menaruh kepala di meja sambil berpikir sehingga menemukan ide baru untuk penyelesaian masalah. Siswa mengalihkan pemikiran mereka dengan kegiatan lain, seperti mencoret-coret kertas, melipat-lipat pojok lembar soal, berbicara sendiri dan menengadahkan kepala untuk memikirkan cara penyelesaian masalah. (Firdaus, 2017; Tandiling, 2006).

Pada tahap ini, siswa mengalihkan pemikiran mereka dengan aktifitas lain 
dengan mengingat-ingat informasiinformasi yang mereka dapat dari tahap sebelumnya. Hal ini karena siswa mengalami pemikiran buntu akibat jenuh, sehingga siswa mengalihkan perhatian kemasalah lain diantaranya melamun, berbicara dengan temannya, merasa gelisah, namun tetap mengingat kembali ide-ide sebelumnya sehingga muncul inspirasi (Putri et al., 2019; L. N. Sari, 2016; Sitorus \& Masrayati, 2016).

Sedangkan pada penelitian (Wulantina et al., 2015) siswa diam ketika sedang memikirkan ide dalam penyelesaian masalah, siswa diam fokus memperhatikan soal dengan membacanya dalam hati dalam memikirkan ide penyelesaian masalah, siswa diam mengingat-ingat kembali rumus yang paling tepat dalam menyelesaikan soal.

\section{Tahap Iluminasi}

Siswa menentukan ide dari menghubungkan masalah konstektual dengan keadaan atau kejadian disekitar mereka, kemudian siswa menganalisis ide-ide yang ditemukan sehingga siswa dapat menyelesaikan masalah konstektual. Tahap iluminasi sendiri merupakan tahap siswa memecahkan ide-ide mereka kedalam pemahaman yang lebih mudah dipahami, menghubungkan kedalam solusi dan mengaitkan ide-ide.

Pada penelitian (Zabeta et al., 2015) mengungkapkan bahwa adanya dialog yang dilakukan oleh beberapa siswa dalam satu kelompok yang membahas mengenai cara penyelesaian masalah dengan menganalisis ide mereka dengan menghubungkan ide untuk memecahkan masalah yang ada. Sedangkan menurut (Ardiansyah \& Sunaringtyas, 2016; A. P. Sari et al., 2017) siswa menemukan ide dari pemikiran pada tahap sebelumnya untuk memecahkan masalah dengan memberikan jawaban sederhana sesuai dengan pemahaman yang mereka miliki.

Penelitian yang dilakukan oleh (Putri et al., 2019; Sitorus \& Masrayati, 2016) bahwa pada tahap iluminasi siswa menemukan ide dari pengalaman masa lalu dan terinspirasi dengan benda disekitar untuk menyelesaikan soal. Berbeda dengan penelitian (L. N. Sari, 2016) bahwa siswa merasa pikirannya segar kembali, secara tiba-tiba ia menemukan ide.

\section{Tahap Verifikasi}

Tahap Verifikasi merupakan tahap memeriksa ide atau jawaban dari masalah yang ada. Pada tahap ini siswa memeriksa ide atau jawaban mereka. Memeriksa dan memverifikasi ide 
mereka dilakukan secara mandiri, guru dan bersama teman-temannya. Siswa mempresentasikan ide mereka kemudian dibahas bersama-sama oleh guru dengan memeriksa, mencoba dan membuktikan ide yang benar dengan benda kongkret disekitarnya sehingga akan didapatkan ide atau jawaban yang tepat dan unik.

Siswa menghitung ulang hasil dari jawaban yang telah diperoleh dengan memeriksa kembali jawaban mereka dan mengujinya bersama guru. Kemudian siswa menemukan solusi yang inovatif, unik, realitas, dan terhubung dengan mata pelajaran lain (Firdaus, 2017; A. P. Sari et al., 2017; Sitorus \& Masrayati, 2016). Sedangkan (Novita et al., 2018) mengungkapkan bahwa seseorang mengecek dan menguji solusi atau jawaban yang telah diperoleh.

Pada tahap verifikasi menurut (Saefudin, 2011; Wulantina et al., 2015) siswa dengan cenderung berhati-hati dalam mengambil kesimpulan, ia memeriksa terlebih dahulu perhitungan atau ide yang diperolehnya, kemudian mengujinya dengan menyocokkan informasi yang diketahui, serta memeriksa kembali sebelum mengambil keputusan setelah yakin, siswa menyimpulkan jawaban.

\section{SIMPULAN}

Proses pembelajaran untuk meningkatkan berpikir kreatif siswa dapat disusun berdasarkan prinsip dan karakteristik pendekatan Realistic Mathematics Education (RME). Terdapat 3 prinsip dan 5 karakteristik dalam RME dan ditekankan dengan aspek berpikir kreatif siswa didalam proses pembelajaran sehingga dapat meningkatkan berfikir kreatif siswa.

Tahapan proses berpikir kreatif siswa melalui RME pada materi pecahan yakni siswa diberikan masalah konstektual kemudian siswa melakukan aktifitas membaca dan memahami masalah konstektual pada tahap orientasi. Pada tahap persiapan, siswa melakukan aktifitas membaca ulang masalah konstektual kemudian menyusun strategi untuk menyelesaikan masalah. Tahap inkubasi, siswa malakukan aktifitas lain yang tidak berhubungan dengan penyelesaian masalah sehingga pada akhirnya muncul ide. Tahap iluminasi, siswa menganalisis ide yang mereka miliki sehingga didapatkan solusi atau jawaban dari masalah. Tahap verifikasi, siswa memeriksa kembali ide atau jawaban mereka.

Saran dari peneliti guna meningkatkan berpikir kreatif siswa, guru dapat menggunakan pendekatan- 
pendekatan dalam matematika salah satunya dengan pembelajaran yang menerapkan pendekatan berdasarkan prinsip dan karakteristik Realistic Mathematic Education (RME). Guru juga harus terus berkreasi dengan pembelajaran yang menarik dan menyajikan materi yang memudahkan siswa untuk lebih mudah memahami materi dan siswa mengetahui konsep secara mandiri dari suatu materi yang diajarkan.

\section{DAFTAR PUSTAKA}

Anggo, M. (2011). Pemecahan Masalah Matematika Kontekstual untuk Meningkatkan Kemampuan Metakognisi Siswa. Edumatica, 01(02), 35-42.

Ardiansyah, A. S., \& Sunaringtyas, A. D. (2016). Identifikasi Proses Berpikir Kreatif Siswa dalam Menyelesaikan Masalah Tipe Multiple Solution Task. Prosiding Seminar Nasional Matematika IX 2015, 268-279.

Dhoruri, A. (2010). Meningkatkan Kemampuan Pemecahan Masalah Matematika Siswa SMP melalui Pembelajaran dengan Pendekatan Pendidikan Matematika Realistik (PMR). Seminar Nasional Matematika Dan Pendidikan Matematika (LSM).

Firdaus, H. P. E. (2017). Analisis Proses Menyelesaikan Masalah Matematika Berdasarkan Gaya Belajar Siswa Sekolah Dasar Pada Materi Operasi Perkalian Dan
Pembagian Pecahan. Gammath: Jurnal Ilmiah Program Studi Pendidikan Matematika, 1(1), 3849.

https://doi.org/10.32528/GAMMAT H.V1I1.421

Hadi, S. (2018). Pendidikan Matematika Realistik (2nd ed.). PT. RajaGrafindo Persada.

Haryanti, T. (2017). Penerapan Pendekatan Realistic Mathematics Education (RME) Pada Materi Pecahan Terhadap Hasil Belajar Matematika Siswa Kelas IV SD Segugus Hos Cokroaminoto Kecamatan Kutoarjo Kabupaten Purworejo Tahun Pelajaran 2011/2012.

Hasyim, I. (2017). Penerapan Pendekatan Realistic Mathematics Education (RME) untuk Meingkatkan Hasil Belajar Siswa pada Pelajaran Matematika di Kelas II MIN Miruk Aceh Besar. UIN Ar-Raniry Banda Aceh.

Heruman. (2007). Model Pembelajaran Matematika di Sekolah Dasar. Remaja Rosdakarya.

Ichwatun, A. (2015). Pengaruh Metode RME (Realistic Mathematic Education) Berbasis Scientific Approach Terhadap Hasil Belajar Siswa pada MaPel Matematika Materi Sifat Bangun Datar Kelas III MI NU 05 Tamangede Kec. Gemuh Kab. Kendal. Universitas Islam Negeri Walisongo Semarang.

Jupri, A. \& K. Y. (2019). Pengembangan Desain Pembelajaran Matematika Realistik untuk Menumbuhkembangkan Kemampuan Pemecahan Masalah dan Komunikasi Matematika Siswa. 
Journal of Chemical Information and Modeling, 53(9), 1689-1699. https://doi.org/10.1017/CBO978110 7415324.004

Manurung, M. M., Windria, H., \& Arifin, S. (2019). Desain Pembelajaran Materi Himpunan Dengan Pendekatan Realistic Mathematics Education (RME) Untuk Kelas VII. Jurnal Derivat: Jurnal Matematika Dan Pendidikan Matematika, 5(1), 19-29. https://doi.org/10.31316/j.derivat.v5 i1.143

Nalole, M. (2008). Pembelajaran Pengurangan Pecahan Melalui Pendekatan Realistik Di Kelas V Sekolah Dasar. Inovasi, 5(3), 136147.

Novita, T., Widada, W., \& Haji, S. (2018). Metakognisi Siswa dalam Pemecahan Masalah Matematika Siswa SMA dalam Pembelajaran Matematika Berorientasi Etnomatematika Rejang Lebong. Jurnal Pendidikan Matematika Raflesia, 3(1), 41-54. https://doi.org/https://doi.org/10.31 186/jpmr.v3i1.6286

Prianggono, A. (2010). Analisis Proses Berpikir Kreatif Siswa Sekolah Menengah Kejururuan ( Smk ) Dalam Pemecahan Dan Pengajuan Masalah. 133-142.

Prianto, A., Subanji, S., \& Sulandra, I. (2016). Berpikir Kreatif Dalam Pembelajaran Rme. Jurnal Pendidikan - Teori, Penelitian, Dan Pengembangan, 1(7), 1442-1448. https://doi.org/10.17977/jp.v1i7.659 3

Purwaningrum, J. P. (2016). Mengembangkan Kemampuan
Berpikir Kreatif Matematis Melalui

Discovery Learning Berbasis

Scientific Approach. Refleksi Edukatika, 6(2), 145-157. https://doi.org/10.24176/re.v6i2.613

Putri, Y. D. L., Sutriyono, \& Pratama, F. W. (2019). Analisis Proses Berpikir Kreatif Siswa Ditinjau dari Gaya Kognitif Berdasarkan Teori Wallas (Vol. 6, Issue 1).

Saefudin, A. A. (2011). Proses Berpikir Kreatif Siswa Sekolah Dasar ( SD ) Berkemampuan Matematika Tinggi Dalam Pemecahan Masalah Matematika Terbuka. Seminar Nasional Matematika Dan Pendidikan Matematika.

Saleh, M., Charitas, R., Prahmana, I., \& Isa, M. (2018). Improving the Reasoning Ability of Elementary School Student Through the Indonesian Realistic. Journal on Mathematics Education, 9(1), 4154.

Sari, A. P., Ikhsan, M., \& Saminan, S. (2017). Proses Berpikir Kreatif Siswa dalam Memecahkan Masalah Matematika Berdasarkan Model Wallas. Beta Jurnal Tadris Matematika, $\quad$ 10(1), 18. https://doi.org/10.20414/betajtm.v1 0i1.102

Sari, L. N. (2016). Proses Berpikir Kreatif Siswa SMP dalam Memecahkan Masalah Matematika Nonrutin Ditinjau dari Kemampuan Matematika. Kreano, Jurnal Matematika Kreatif-Inovatif, 7(2), 163-170. https://doi.org/10.15294/kreano.v7i 2.5919

Sitorus, J., \& Masrayati. (2016). Students' creative thinking process 
stages: Implementation of realistic mathematics educationac. Thinking Skills and Creativity, 22, 111-120. https://doi.org/10.1016/j.tsc.2016.0 9.007

Sulistiyowati, Z. (2014). Meningakatkan Hasil Belajar Matematika Tentang Konsep Pecahan dan Pengurutan Melalui Pendekatan Realistic Mathematics Education (RME) Pada Siswa Kelas IV SD Negeri Karanggayam Kecamatan Pleret Bantul (Vol.

https://doi.org/10.1017/CBO978110 7415324.004

Tandiling, P. (2006). Profil Proses Berpikir Siswa dalam Pemecahan Masalah Matematika Materi Luas Permukaan dan Volume Bangun Ruang Kubus dan Balok Ditinjau dari Tingkat Kemampuan Berpikir Kreatif di Kelas VIII C SMP Negeri 5 Jayapura (Vol. 5, Issue 2).

Warsito, W., Nuraini, Y., \& Sukirwan, S. (2019). Desain Pembelajaran Pecahan melalui Pendekatan Realistik di Kelas V. Mosharafa: Jurnal Pendidikan Matematika, 8(1), 25-36. https://doi.org/10.31980/mosharafa. v8i1.381

Wulantina, E., Kusmayadi, T. A., \& Riyadi. (2015). Proses berpikir kreatif siswa dalam pemecahan matematika pada siswa kelas $\mathrm{X}$ MIA SMA 6 Surakarta. Jurnal Elektronik Pembelajaran Matematika, 3(6), 671-682.

Zabeta, M., Hartono, Y., \& Putri, ratu ilma indra. (2015). Desain Pembelajaran Materi Pecahan Menggunakan Pendekatan PMRI di Kelas VII. Beta, 8(1), 86-99. 